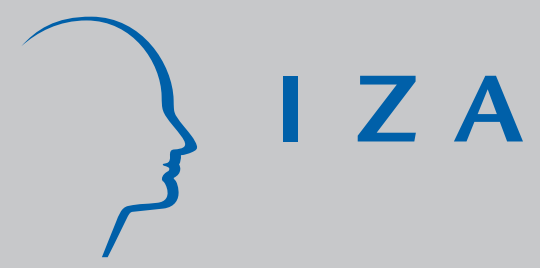

IZA DP No. 799

General Human Capital and Employment Adjustment in the Great Depression: Apprentices and J ourneymen in UK Engineering

Robert A. Hart

J une 2003 


\title{
General Human Capital and Employment Adjustment in the Great Depression: Apprentices and Journeymen in UK Engineering
}

\author{
Robert A. Hart \\ University of Stirling and IZA Bonn
}

Discussion Paper No. 799

June 2003

IZA

P.O. Box 7240

D-53072 Bonn

Germany

Tel.: +49-228-3894-0

Fax: +49-228-3894-210

Email: iza@iza.org

This Discussion Paper is issued within the framework of IZA's research area Internationalization of Labor Markets. Any opinions expressed here are those of the author(s) and not those of the institute. Research disseminated by IZA may include views on policy, but the institute itself takes no institutional policy positions.

The Institute for the Study of Labor (IZA) in Bonn is a local and virtual international research center and a place of communication between science, politics and business. IZA is an independent, nonprofit limited liability company (Gesellschaft mit beschränkter Haftung) supported by the Deutsche Post AG. The center is associated with the University of Bonn and offers a stimulating research environment through its research networks, research support, and visitors and doctoral programs. IZA engages in (i) original and internationally competitive research in all fields of labor economics, (ii) development of policy concepts, and (iii) dissemination of research results and concepts to the interested public. The current research program deals with (1) mobility and flexibility of labor, (2) internationalization of labor markets, (3) welfare state and labor market, (4) labor markets in transition countries, (5) the future of labor, (6) evaluation of labor market policies and projects and (7) general labor economics.

IZA Discussion Papers often represent preliminary work and are circulated to encourage discussion. Citation of such a paper should account for its provisional character. A revised version may be available on the IZA website (www.iza.org) or directly from the author. 
IZA Discussion Paper No. 799

June 2003

\section{ABSTRACT}

\section{General Human Capital and Employment Adjustment in the Great Depression: Apprentices and Journeymen in UK Engineering*}

The relationship between training and firm-level employment adjustment given an unanticipated fall in product demand has been central to human capital theory. The most cataclysmic negative output shock occurred in 1929/30. At this time, easily the most important source of United Kingdom general training was the apprenticeship system. Using data collected by the Engineering Employers' Federation (EEF), this paper examines the impact of the Great Depression on numbers of apprentices and skilled journeymen. Statistics cover eight skilled engineering occupations in 38 local labour markets over the period 19281938. Relative employment adjustment responses of apprentices and journeymen accord well with general human capital arguments.

JEL Classification: E24, J24, N34

Keywords: general human capital, British engineering, Great Depression, employment adjustments

Robert A. Hart

Department of Economics

University of Stirling

Stirling FK9 4LA

Scotland

Email: r.a.hart@stir.ac.uk

\footnotetext{
" I would like to thank the Engineering Employers' Federation for granting me access to their statistical records held at the Modern Records Centre, University of Warwick. I am also grateful for the help of staff at the Centre. David Bell, Julia Darby, Brian Loasby and Ron Shone made helpful suggestions on work in preparation. Elizabeth Roberts provided research assistance. The usual disclaimer applies.
} 
The engineering industry is of supreme importance as a field for industrial training, not only because of its widespread character and of the great variety of its products but also because it comprises a large number of highly skilled occupations, to gain proficiency in which demands systematic instruction both in practice and in theory.

(Ministry of Labour, 1928a)

\section{Introduction}

The effect of firm-level training on employment adjustment given an una nticipated fall in product demand has been central to the human capital analysis of labour market behaviour. The most cataclysmic negative output shock occurred in 1929/30, marking the outset of the Great Depression. By far the dominant form of general training in UK industry when this event occurred was the apprenticeship system. Here, I concentrate on the most important sector of the time, the engineering industry. Training was general because, for example, a fully apprenticed boilermaker in one firm could, in large part, perform the tasks of a boilermaker in another firm. I compare the employment adjustments of apprentices and journeymen, the top skill group in each occupation. An important fact was that there was no special employment protection afforded to apprentices. It is shown that the adjustments of the two groups followed a sequence that was strongly in line with predictions arising from general human capital theory: the downward adjustment of apprentices was delayed significantly in the early Depression years. Another feature of this period was that, due to structural characteristics, northern engineering districts of the UK employed significantly higher ratios of apprentices to journeymen than southern and midland districts. Using this dichotomy, evidence is presented that supports the view that apprentices provided effective substitute labour for journeymen during this critical economic period. 
The empirical analysis is based on United Kingdom data collected by the Engineering Employers' Federation (EEF). ${ }^{1}$ The paper concentrates on the impact of the Great Depression on apprentices and journeymen in eight skilled occupations in engineering. These are fitters, turners, patternmakers, smiths, boilermakers, moulders (iron and steel), brass moulders, and brass finishers. ${ }^{2}$ The regression analyses concentrate on a panel of 27 engineering districts, for which matching unemployment data are available, over the period 1928-1938.

\section{The engineering apprenticeship ${ }^{3}$}

Within U.K. industries in which apprenticeships occurred ${ }^{4}, 2.6$ percent of all male workers were apprenticed in 1925/6. Within engineering at this time, 32 percent of all workers under the age of 21 were apprentices. The period of engineering apprenticeship lasted from 5 to 7 years. ${ }^{5}$ Wor kers almost always trained in one occupation - a fitter or a turner or a boilermaker etc. - gaining little formal knowledge of related occupations. ${ }^{6}$ On the completion of an apprenticeship, individuals were

\footnotetext{
${ }^{1}$ During the 1920s and 1930s, there were between 1800 and 2500 engineering firms in the EEF, representing between 400,000 and 700,000 workers. See Marsh (1965) and Hart (2001) for more details.

${ }^{2}$ See Ministry of Labour (1928a, pp. 50-54) for descriptions of the job tasks involved in these occupations.

${ }^{3}$ Supporting facts for much of this Section are obtained from a detailed and comprehensive survey undertaken by the Ministry of Labour (1928a) - of the UK engineering apprenticeship system. It refers to the years in 1925-1926. It sampled betwen 55 and 60 percent of the industry, with returns from 2534 firms of all sizes and branches of engineering covering 43,923 apprentices and 14,724 so-called learners. Supplementary details are obtained from Ministry of Labour (1928b).

${ }^{4}$ These are metals, chemicals and allied, building and woodworking, printing and paper, textiles and clothing, miscellaneous (incorporating leather, food and drink, distributive, mercantile marine, other).

${ }^{5}$ In 1925/6 about 48 percent of apprentices were serving for 5, 29 percent for 6 , and 18 percent for 7 years.

${ }^{6}$ The narrowness of apprenticeship training and its general failure to produce rounded and flexible journeymen, with an acquired knowledge base across interrelated occupations, had long been recognised by informed observers. In fact, it is a major theme of Tawney (1909) in his critique of the apprenticeship system.
} 
generally required to work a period as a so-calle d 'improver ${ }^{7}$ before full journeyman status and remuneration could be attained.

Most engineering apprentices had only an elementary school background and 99 per cent entered their apprenticeship between the ages of 14 and $16 .{ }^{8}$ The most common forms of recruitment were through personal job applications and through hiring relatives of existing employees. Many newcomers had to serve a period of probation usually between one and twelve months. It was general practice for an apprenticeship to be completed at the age of 21 . Therefore, the length of apprenticeship - of 5, 6 or 7 years - was controlled by the gap between the typical entry age and the 21 - age limit. ${ }^{9}$ Further, different completion spell lengths could apply to the same occupation or the same spell length to different occupations. It follows that the length of apprenticeship did not bear a close relationship to the time required to acquire the relevant skills in a given occupation. ${ }^{10}$ In fact it is safe to make an even bolder inference. Since, the shortest 5-year apprenticeship must have allowed sufficient time to complete the

\footnotetext{
${ }^{7}$ For the vast majority of workers, this interim position lasted between 6 and 24 months, with about one half of workers experiencing a 12-month spell.

${ }^{8}$ In 1925/6, 36 percent of new engineering apprentices were 14 years old, 20 percent 15 and 43 percent 16.

${ }^{9}$ The Ministry of Labour (1928b, p. 83) spelled out the position. "Length of apprenticeship appears to be determined mainly by factors influencing the age of entry, in conjunction with the legal character of the relationship which makes its termination at the age of 21 years desirable, since at the attainment of that age it is open to the apprentice to repudiate the contract. Thus, a fixed age on conclusion, together with a variable age at entry on apprenticeship, account for the extraordinary diversity of periods of training."

$10 "$ "...there appears from the evidence collected to be little support for the view that the period of apprenticeship in the same occupation has any direct relationship to the time actually required for learning, for on the one hand the diversity of period required for apprentices in the same occupation and on the other the similarity in the periods required for different occupations demanding widely varying degrees of manual skill point the determination of the length of apprenticeship on an arbitrary principle rather than on one of design." (Ministry of Labour, 1928b, p. 83)
} 
requisite training then many apprentices must have acquired full training and knowhow significantly before their formal completion dates.

Wages of apprentices were amost all paid at time rates, with prescribed rates varying directly with age. The rates varied across occupations, sectors of the industry and geographical location. Based on 16 engineering geographical districts, Table 1 shows the average wages - in shillings (s.) and pence (d.) - for apprentices and journeymen in four engineering occupations in 1925. A journeyman typically earned more than twice the wage of a final year apprentice.

Table 1 Average weekly wages (time rates) in four engineering occupations: apprentices and journeymen in 1925

\begin{tabular}{|c|c|c|c|}
\hline \multirow[b]{2}{*}{ Occupation } & \multicolumn{2}{|c|}{ Apprentices } & \multirow[t]{2}{*}{ Journeymen } \\
\hline & First Year & Last Year. & \\
\hline Fitters & $\begin{array}{lr}s . & d . \\
10 & 3\end{array}$ & $\begin{array}{ll}s . & d . \\
24 & 10\end{array}$ & $\begin{array}{lr}s . & d . \\
56 & 6\end{array}$ \\
\hline Turners & 106 & $26 \quad 1$ & $56 \quad 6$ \\
\hline Patternmakers & 10 & 24 & $60 \quad 11$ \\
\hline Ironmoulders & 10 & 26 & $60 \quad 0$ \\
\hline
\end{tabular}

Source: Ministry of Labour (1928b, p.116)

Usually, the initial period of the apprenticeship involved 'pure' training; i.e. training that did not involve direct production activity. There are several prominent examples of the type of activity entailed here. Some apprentices spent their first three to six months in the works stores in order to learn the names, functions and maintenance of tools. It was not uncommon to devote the first year of apprenticeship to observing the work performances of skilled journeymen, learning how to read working drawings, and understanding basic engineering principles with particular emphasis on the need for precise measurement and attention to detail. Far less commonly, some firms ran apprenticeship schools that provided basic engineering skills to which the apprentice 
had to attend for an initial period of about four to six months. After acquiring such basic knowledge, apprentices worked directly in their specific occupation but in a controlled environment. Most worked alongside and under the supervision of a journeyman. ${ }^{11}$ By the final year of apprenticeship, unsupervised job tasks were commonly undertaken.

Generally, a worker did not immediately obtain journeyman status on completion of an apprenticeship. First, he had to undertake a period as a so-called improver. The period varied from a few months to 24 months, with about one-half lasting for 12 months. An improver typically earned in the region of $75 \%$ of a journeyman's wage.

How did training relate to wage structure during apprenticeship? While emphasising a range of alternative motivations, the key employer objectives underlying apprentice wage rate setting and productive activity was summed-up in the definitive contemporary study as follows:

“...in the earlier years of apprenticeship the apprentice receives more by way of training than he gives by way of production and his wages in consequence are determined on the basis of his being a liability rather than an asset during that time...in the later years of apprenticeship his remuneration is fixed so as to allow a certain compensation to the employer for the inevitable financial loss sustained in the earlier years of training." (Ministry of Labour, 1928b, pp. 110-111)

The study goes on to state (and to show) that

"...in the first and last years of apprenticeship the wages of apprentices are uniformly less than those of youths of comparable ages in the less skilled occupations."

(Ministry of Labour, 1928b, p.111)

Similarly, and based on statistics on 14 to 19 year-olds in 84 industries, the study reveals "...that the general level of apprentices wages tends to be fixed considerably below that of other juvenile workers not employed under a definite system of training."

\footnotetext{
${ }^{11} 68$ percent of engineering firms reported this work practice in the Ministry of Labour (1928a) survey.
} 
(Ministry of Labour, 1928b, p.115)

To the extent that these objectives were realised, they underline the notion that attempts were made to re-coup the costs of apprenticeship training by paying lower than outside wages during initial training and throughout the later productive phases. This would serve to reduce the need to prolong employment post-apprenticeship for the purpose of lengthening the investment amortisation period. A critical related question is as follows. Given that an apprenticeship lasted for a long duration, how secure was employment during that time?

The evidence points firmly to the fact that the majority of engineering firms were able to layoff apprentices as the economic need required. ${ }^{12}$ First, 69 percent of engineering apprentices in 1925 served under verbal agreements with the remainder under indentures or other written agreements. Second, collective bargaining over the employment conditions of apprentices was rare throughout the engineering industry. This was certainly the case with regards to the principal employers' federation studied here. Up to 1937, the EEF refused to allow apprenticeship issues to be included on union bargaining agendas. ${ }^{13}$ Thirdly, while there was a lack of collective bargaining it was frequent practice for employers to require apprentices (or their guardians) to sign forms of agreement that spelled out the obligations of both sides during the period of

\footnotetext{
${ }^{12}$ In an autobiography devoted to a lifetime's work in the railway industry, Thorley (1975) describes his experience as an engineering apprentice fitter in locomotive maintenance for 5 years from 1928 to 1932. In March 1932, he was given notice to leave his firm (London, Midland and Scottish Railway) one-week after the apprenticeship was completed. ${ }^{12}$ The author notes

"...it was widespread practice to discharge all those who had completed their apprenticeships, not only on the railway but also in industry, with the opportunity of returning as vacancies occur. But vacancies were then few; I knew several tradesmen who accepted jobs as porters at busy stations in the summer in order to preserve unbroken service...." (Thorley, 1975, p.84)

${ }^{13}$ Trade- union negotiation over apprentices' rates of pay was forced on the EEF by the apprentices' strikes of 1937.
} 
apprenticeship. The most common of these, the so-called Form B, included among its terms the right of the employer "to su spend the apprentice from employment and training during periods of slackness of trade, etc., and the provisions of the agreement cease to operate during the period of suspension."

Could apprentices provide a source of substitute labour for journeymen? Certainly, a strong contemporary union view was that, especially in the trough Depression years, some engineering employers treated apprentices as a form of relatively inexpensive substitute labour for equivalent skilled journeymen. Ryan (1999) provides evidence in support of this contention and quotes a view, expressed in 1933, from an employer in the marine engineering sector:

"..owing to the great volume of unemployment which has prevailed in recent years, some employers have traded upon apprenticeship to the extent of using them to do current work and, when their apprenticeship has ceased, discharged them and taken on new apprentices...many employers are using apprentices as form of cheap labour at the present time, evading all responsibility in respect of the boys' training." 14

Perhaps the main factors that combined to give credence to this view was the relatively long period of apprenticeship, the narrowness of the necessary skill acquisition, and the simplification of production processes. Technologic al advances in the decades preceding the Depression served to narrow the range of skill requirements within several occupations. Contributory factors included the breakdown of processes into simpler subdivisions as well as the introduction of automatic and semiautomatic machines. In part, the industry met this problem by creating the job position of 'learner', especially in occupations like stamping and machining were job tasks were repetitive. Like an apprentice, a learner trained for

\footnotetext{
${ }^{14}$ Taken from microfilm records from the EEF archive.
} 
between 5 and 7 years but with a somewhat less rigid regime of training procedure and even less secure tenure. But without doubt, it was common for apprentices - from an early stage in their apprenticeship - both to specialise in a quite narrowly defined trade and to work directly as production operatives.

Based on a locomotive works with 4000 employees, Tawney (1909) gives the following description of the experience of the vast majority of boy apprentices.

"They are apprenticed either as fitters, as erectors, or as turners; for in this firm specialisation is carried out so that fitting and erecting, which are almost always combined, are here separated. On entering the works the lad who is going to be a fitter goes straight into the fitting shop and learns nothing else; a lad who is going to be a turner goes to the machine shop and does not learn fitting. Moreover, in the machine shop, specialisation has proceeded still further. There are a large number of machines which are worked, not by men who have served their time and acquired a general knowledge of machinery (i.e. qualified turners), but by youths who are kept to a single machine, who become capable at that particular kind of work, and who...do not get a general knowledge of machinery...".

Generalising, and based on additional interviews with engineering employers, Tawney goes on to report that these

"...specialised machine-minders form a growing proportion of the total number of machines employed in engineering works, owing to the continual invention of simplified machines adapted to a particular class of work done by particular firms....."

The ability of firms to employ many apprentices in direct production roles at a very early stage reinforces the notion that firms could attempt to balance marginal costs and returns over the period of apprenticeship. This reduced the necessity of prolonging employment in post-apprenticeship years in order to recover initial sunk costs.

Finally, and of some importance to the subsequent analysis, the ratios of apprentices to journeymen were appreciably higher in northern districts of the UK (including 
those in Scotland and Northern Ireland) than in the midlands and the south. In the 27 districts studied here, ratios that averaged about 4:10 in northern districts were double the 2:10 average in midlands/southern districts (see Figure 2). Many southern engineering firms employed no apprentice labour whatsoever. ${ }^{15}$ Industrial structure provided a major reason for these differences. Older traditional industries of the north, like marine engineering, had a long established history of apprenticeship while the more modern industries of the south, like motor vehicle manufacture, perceived less need for producing trained labour along this route. One reason for this (Ministry of Labour, 1928a, p.8) related to the system of 'up-grading' that was common in more modern firms. Here, production processes were broken down into relatively simple parts and non-apprenticed youths were promoted from sub-process to sub-process according as and when they satisfied laid-down efficiency criteria.

\section{General human capital and employment adjustment}

I now turn to the implications of the main stylised facts of the previous section in order to assess the likely relative employment reactions of apprentices and journeyman given the speed of onset and the severity of the Great Depression. To simplify matters, I ignore the position of improver, which marked the period between apprenticeship and journeyman status. This in no way detracts from the basic analysis.

\footnotetext{
${ }^{15}$ The Ministry of Labour (1928a, p. 8), provides further details. "There were relatively more firms in southern than in northern districts without apprentices or learners. Thus in Merseyside and Barrow district all the firms submitting returns employed apprentices or learners, and in all other districts north of the Midlands the proportion of firms which had no boys under a definite system of training were only from 10 to 30 percent of the total; on the other hand, in the Midland and Southern districts including London, the proportions of firms without boys in training varied from about 38 to 64 per cent."
} 
Consider an apprenticeship under indenture or written agreement. ${ }^{16}$ This applied to about $30 \%$ of engineering apprentices. The consequences of a negative demand shock for the relative employment of journeymen and indentured apprentices is considered in Figure 1. For simplicity, discounting is ignored.

During the period of apprenticeship (i.e. from a to c) the wage-experience profile rises from e to h. Then, the wage rises steeply to w when journeyman status is achieved. ${ }^{17}$ Related productivity - measured in va lue terms - follows the path $x-y-q_{1}$, with a- $x$ representing the initial period of pure training. Following the demand shock, productivity falls at each level of experience to $\mathrm{x}-\mathrm{z}-\mathrm{q}_{2}$. Journeymen become unprofitable. By contrast, a significant proportion of apprentices, in fact all those to the right of $b$, remain profitable. If the demand downturn is judged to be long lasting, then some apprentices to the left of $b$ will remain in employment given an expected positive present value. ${ }^{18}$ The implications are that (a) journeymen will be fired, (b) apprentices on the whole will not be fired. But if a-e-h-c exceeds $x-z-c$ then fewer apprentices will be taken on.

Apprenticeship training was general; in the main, acquired skills were transferable between competing firms. Therefore, apprentices earning a wage between $\mathrm{f}$ and $\mathrm{h}$ had a potential incentive to quit the firm and find alternative employment that better

\footnotetext{
${ }^{16}$ There was little difference between indentures and written agreements. The latter simply incorporated somewhat less formal language than the former. Usually they both detailed various conditions governing the period of apprenticeship, the wage scales that applied during apprenticeship, and the trade under which the apprentice was to be taught. It was usual to bind the apprentices' parents or guardians as a third party to the agreement.

${ }^{17}$ Representative data for $\mathrm{e}, \mathrm{h}$ and $\mathrm{w}$ are presented in Table 1.

${ }^{18}$ Other reasons for retaining 'unprofitable' apprentices derive from the so-called 'opportunity cost' literature of economic growth (Saint -Paul, 1993). For example, Bean (1990) explains pro-cyclical productivity in terms of firms diverting labour towards training when marginal product is low (recessions) and towards production when marginal product is high (booms).
} 
matched their marginal product. The question arises, therefore, as to why $70 \%$ of apprentices worked under verbal (i.e. implicit) agreements rather than legally binding contracts. There are strong reasons for supposing that many such individuals were 'bound' to their apprenticeships without the need for a formal contract.

Figure 1 Employment adjustments to an output shock: indentured apprentices and journeymen

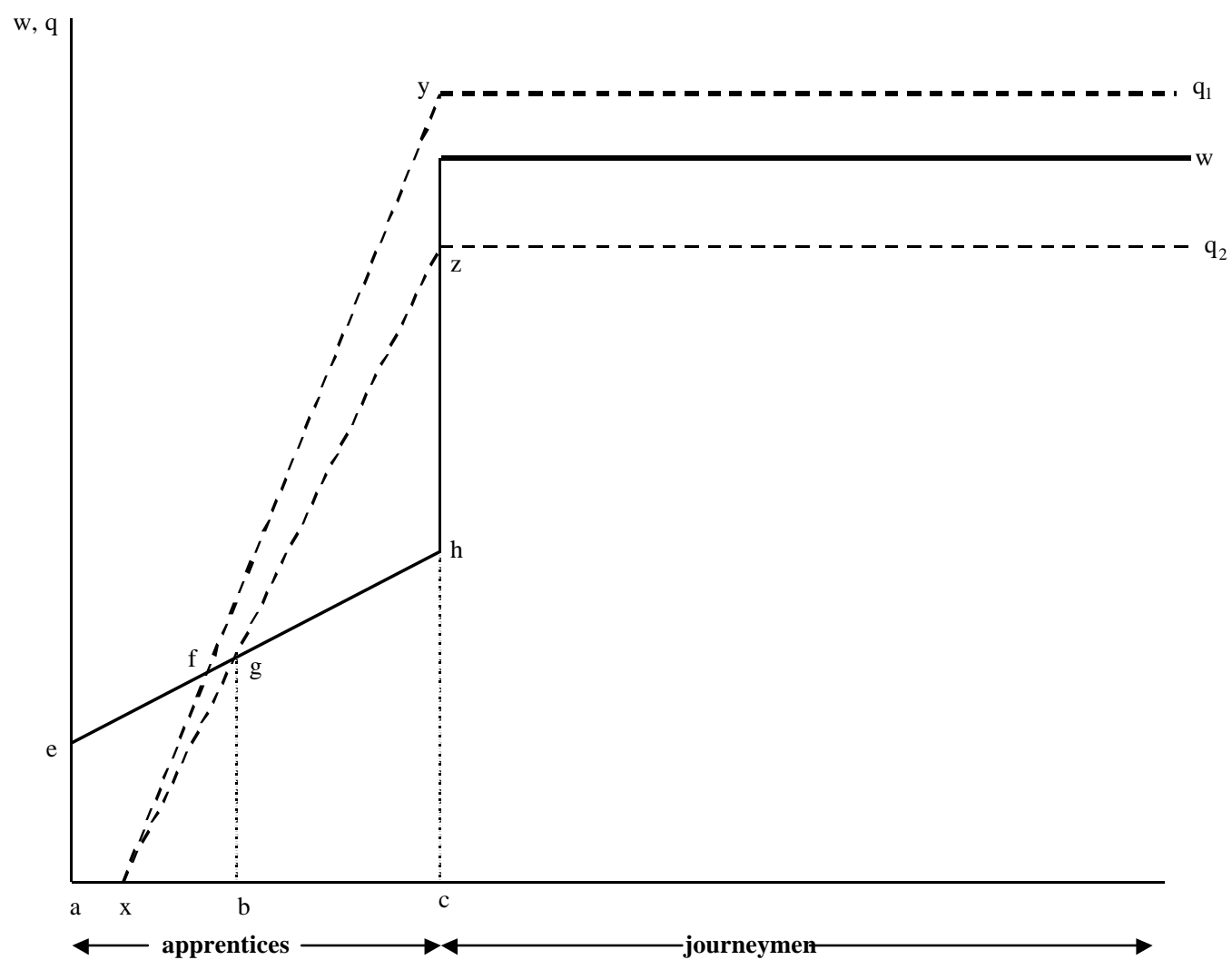

Relatively few engineering apprentices completed their training in other firms. These so-called 'turnovers' accounted for only 1.9 percent of all male apprentices in engineering in 1925 (Ministry of Labour, 1928b. p.60). ${ }^{19}$ The above analysis would have predicted a far higher percentage if non-indentured, partly completed,

\footnotetext{
${ }^{19}$ This compares with 9.2 percent of apprentices who failed to complete their apprenticeships and were entirely lost to the industry. Evidence suggests that the probability of quit was independent of whether an apprentice was indentured or employed under a verbal agreement.
} 
apprentices had been able to move to equate wage and marginal product. What prevented them from doing so? First, virtually all apprentices were aged between 14 and 21 and would have lived with their parents or guardians. For the majority, there would have been little opportunity to venture outside their local labour market, or engineering district. ${ }^{20}$ In other words, job mobility for many apprentices would have been restricted to firms operating in close proximity to one another. Given this restriction, there would have been strong incentive among local employers to collude in order to prevent competition over the employment of one another's apprentices and thereby eroding favourable wage/productivity advantages. Second, where the apprenticeship system was strongest - in northern districts of the U.K. - many firms tended to hire more apprentices than necessary to replenish their turnover of journeymen (see Section 4). Such over-supply would also have served to restrict inter-firm mobility. Third, even in the years leading up to the Great Depression, unemployment was high. From 1926 to 1930 the unemployment rate did not fall below an average of 10 percent for the districts analysed here. In northern districts, the rates were well in excess of 10 percent, with examples of rates double this figure not uncommon (see Hart and MacKay, 1975, Table A5). For many apprentices, this was not a climate in which to search for new job opportunities or to sever accumulated work experience and reputation in the current work environment.

There is an important caveat to the scenario depicted in Figure 1. Even though many apprentices would have remained profitable when productivity fell, their propensity to experience job layoff may have differed little from journeymen if the two parties

\footnotetext{
${ }^{20}$ Interestingly, one of the main reasons reported for individuals failing to complete their apprenticeships was the fact that their parents moved home to live in another geographical region (Ministry of Labour, 1928b, p.61).
} 
represented complementary labour inputs. It was noted in the previous section, for example, that a common form of apprenticeship training involved working under the supervision of - or at least in conjunction with - a journeyman. So, for many apprentices/journeymen combinations, both parties may have been laid-off if the joint marginal product of the work team fell below their average wage. However, even in firms were strong elements of complementarity existed, there are reasons for believing that there were also instances of substitutability between apprentices and journeymen. As argued earlier, there is little doubt that many individuals completed their training before the end date of their apprenticeship. The critical evidence is that the length of apprenticeship ( $\mathrm{a}-\mathrm{c}$ in Figure 1) was determined by an individual's entry age (21 was the typical completion age) and this could vary from 14 to 16 in the same occupation. Therefore, apprentices could reach $q_{1}$ productivity level before point $y$. Where this occurred, firms at any given time employed a stock of relatively cheap workers who could work independently of journeymen and who, therefore, represented close labour substitutes. The existence of such workers would have enhanced firms' abilities to reduce rapidly their stock of journeymen when $q_{l}$ fell to $q_{2}$

Available data do not allow us to ascertain the relative numbers of fully trained workers still under apprenticeship district by district. However, we have an indirect method for obtaining some insight into the degree to which apprentices were treated as substitute labour inputs when productivity fell. As already noted, northern engineering districts employed considerably higher proportions of apprentices to journeymen. To the extent that this resulted in greater stocks of fully, or near fully, trained apprentices at the outset of the Depression, then we would expect to observe more significant reductions of journeymen, and less significant reductions of 
apprentices, than in southern districts. One existing piece of supporting evidence relates to EEF firms in Clydeside that are reported to have displayed a tendency during the Depression to shed high paid operatives and to retain low paid apprentices (McKinlay, 1996).

\section{Cyclical changes in numbers of apprentices and journeymen, 1902-1938}

Before turning to estimation, I deal briefly in this section with several key aspects of the relative cyclical characteristics of the employment of apprentices and journeymen.

Starting with a long-term perspective, Figure 2 shows the ratio of engineering workers aged 14 to 21 (described as apprentices, boys and youths ${ }^{21}$ ) to journeymen between 1902 and 1938 in eight occupations. Three features stand out. First, the immediate post war years marked strong rises in the ratios. This represented an attempt by the industry to replenish its stock of young recruits given the wartime disruption to the labour supply of this age group. ${ }^{22}$ Second, following a period of post-war adjustment, the ratios in the late 1920 s were generally lower than their pre-war equivalents. ${ }^{23}$

Third, and most importantly in relation to previous discussion, the proportions rose markedly for several years at the onset of the Depression in 1929. Then, starting in 1931/2, they declined to below their pre-war levels before regaining or surpassing these levels on the run-up to the Second World War.

\footnotetext{
${ }^{21}$ Roughly 30 percent of this group were apprentices in the mid-1920s.

${ }^{22}$ Training young workers dur ing the Great War was difficult for four reasons. First, there were relatively few skilled men due to war service. Second, abnormally high output demand necessitated the adoption of very specialised techniques of production. Third, young trainees were liable to military call up when they reached 18 . Fourth, the high incentive wages paid for repetitive wartime work reduced the desire to work at lower-level apprenticeship wages. Immediately following the war, the Ministry of Labour's Interrupted Apprenticeship scheme provided cash subsidies to the industry in an attempt to provide earnings that would have been paid if the training had not been interrupted. In engineering, 16,000 workers resumed their training under this scheme.

${ }^{23}$ Although, the reductions were relatively small for apprenticeships alone over the period 1909 to 1925 (see Ministry of Labour, 1928b, pp. 44-45).
} 
The main focus of attention is the period from 1928 to 1938 . Figure 3 shows the ratios of apprentices to journeymen as well as the rate of unemployment for this period. $^{24}$ Taking our sample of 27 districts together, it is clear that the onset of the Depression in 1929 coincided with violent increase in unemployment over the next two years. The weighted- average unemployment in the 27 districts was 17 percent in 1928 and rose to 37 percent by 1933 . Thereafter, it fell to its pre-Depression level by 1937. This coincided with a rise in the ratio of apprentices to journeymen from about 3:10 in 1928 to slightly over 4:10 in 1932 . In the following year, the ratio returned to its pre-Depression level. The comparable movements in northern districts (including Scotland and Northern Ireland) and in Scottish and Northern Irish districts involved considerably higher ratios of apprentices. These areas recorded average ratios in excess of 5:10 in the depth of the Recession. ${ }^{25}$ In sharp contrast, the average ratios in southern/midland districts were (a) significantly lower than their northern counterparts and (b) displayed less overall cyclical responsiveness. They deviated little from ratios of 2:10 over the entire period. Of course, these summary graphs are aggregate and, as

\footnotetext{
${ }^{24}$ Using the rate of change of unemployment produces a similar picture.

${ }^{25}$ It is worth putting these ratios into some sort of perspective. Suppose that a typical engineering firm in 1928 based employment requirements on expected modest and stable economic growth with no anticipated major changes in capital and organisational structure. Then, the replacement ratio of apprentices to journeymen would roughly equal their respective tenure lengths. So, for example, a five-apprenticeship system coupled with an expected 25-year tenure for a journeyman would translate into a required ratio of 2:10.
} 
Figure 2 Ratios of Apprentices, Boys and Youths to Journeymen, 1902-1938 ${ }^{\text {a }}$

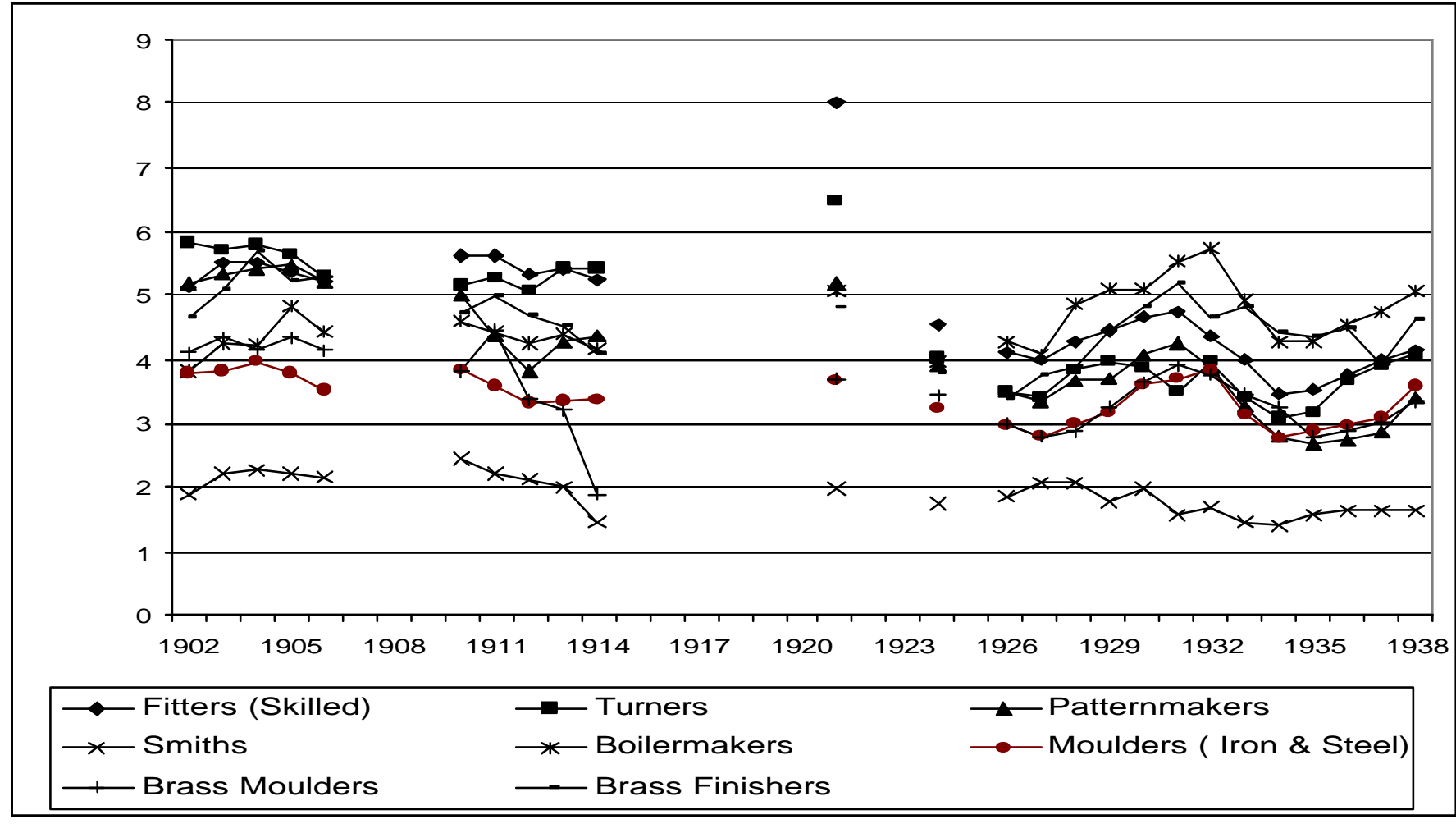

${ }^{a}$ Left-hand side axis denotes numbers of apprentices/boys/youths per 10 journeymen.

Source: EEF Archive, MSS.237/13/3/57 -61. 


\section{Figure 3 Ratios of apprentices to journeymen and the rate of unemployment, 1928 -1938 (based on 27 EEF districts)}

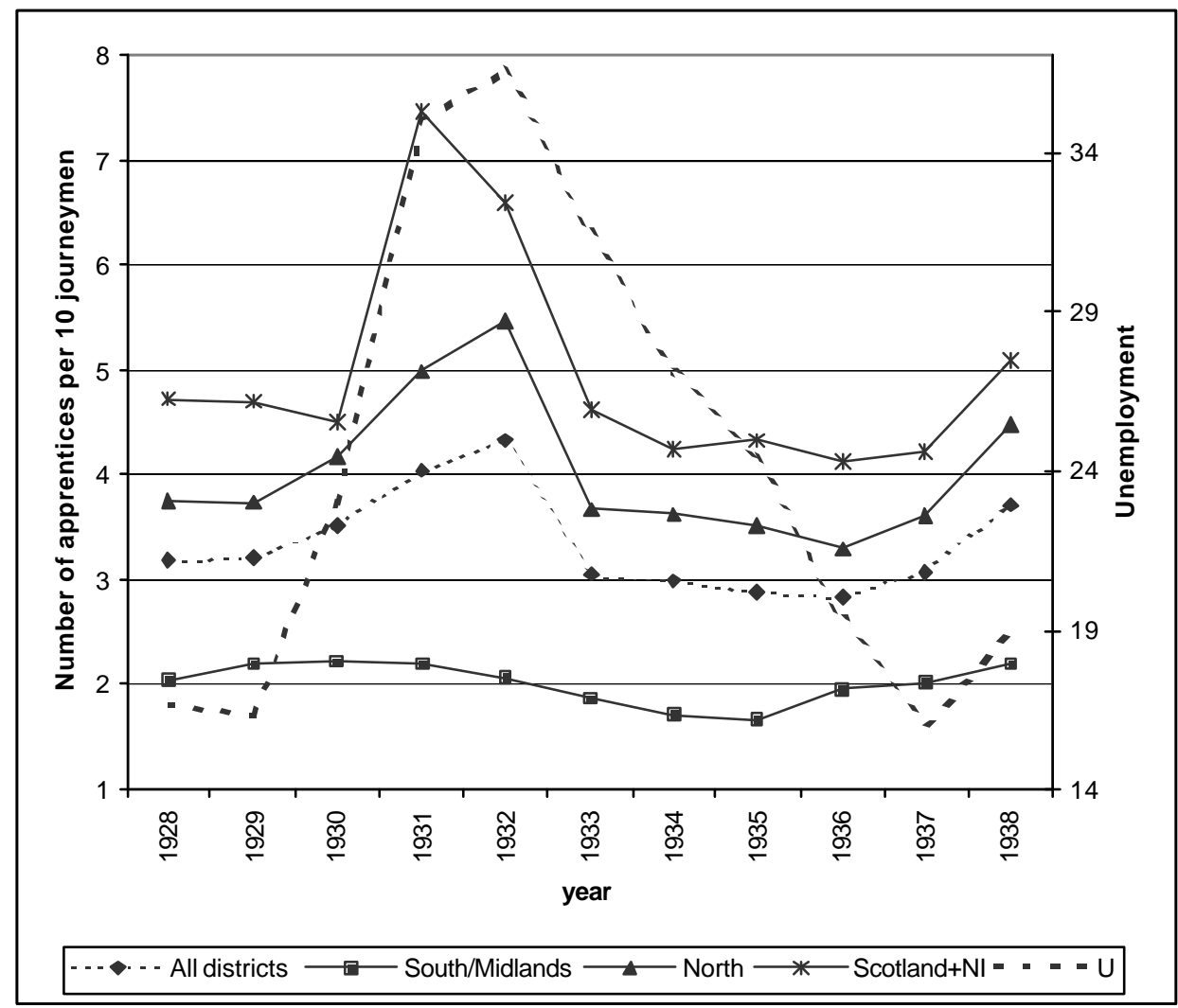

investigated in the following section, district/ occupation breakdowns would be expected to reveal more time-series variation.

\section{Employment equations, estimation and results}

Empirical work on the adjustments of apprentices and journeymen is undertaken for the period 1928-1938. It is based on 27 district associations of the EEF and covers eight occupations. The number of included districts is determined by the availability of matching unemployment statistics. Data details are given in the Appendix. 
My core employment formulations are the same for both apprentices and journeymen.

Employment is taken to depend on a quadratic time trend, district-level cyclical

fluctuations in demand (as proxied by deviations of district unemployment rates from quadratic trends), and on the quality of recruitment (or job match). I illustrate the specification in the case of apprentices. Let, $a_{i r t}$ represent the logarithm of the number of apprentices in occupation $\mathrm{i}$ and district $\mathrm{r}$ at time $\mathrm{t}$.

(1) $a_{i r t}=\beta_{1}+\beta_{2} t+\beta_{3} t^{2}+\beta_{4}\left(u_{r t}-\delta_{1}-\delta_{1} t-\delta_{3} t^{2}\right)+\beta_{5} d_{r}+\beta_{6} \lambda_{i}+\beta_{7} t \cdot \lambda_{i}+\varepsilon_{i r t}$

where $u_{r t}$ is the logarithm of the district unemployment rate at time $t^{26}, d_{r}$ is a district identifier, $\lambda_{\mathrm{i}}$ represents individual job match, and $\varepsilon_{\text {itt }}$ is a random error term. The interaction between job match and time reflects the fact that firms gain knowledge in how to find and recruit apprentices of suitable quality.

First differencing equation (1) gives

(2) $\Delta a_{i r t}=\gamma_{1}+\gamma_{2} t+\gamma_{3} \Delta u_{r t}+v_{i}+\Delta \varepsilon_{i r t}$

where $v_{i}=\beta_{7} \lambda_{i}, \gamma_{2}=2\left(\beta_{2}-\beta_{4} \delta_{3}\right)$, and $\gamma_{3}=\beta_{4}$.

For estimation purposes, I modify equation (2) in three ways. First, I relax the implicit restriction of a unity coefficient on the lagged number of apprentices and allow this to be freely estimated. Second, I allow for lagged terms in the rate of

\footnotetext{
${ }^{26}$ The unemployment rate in each district is taken to proxy the local state of demand for each occupational group in that market. So, a given rate may be taken to represent demand for up to eight occupational groups. It may be the case that groups in the same district are affected by a common set of unobserved district-level variables. In this case, the standard errors may be downwardly biased (Moulton, 1990). No attempt is made to correct for this possibility here.
} 
change of unemployment. Third, I capture the time trend more generally by using year dummies.

Recalling that I follow the same procedure for the employment of journeymen, my two estimating equations are given by

$$
a_{i r t}=b a_{i r t-1}+\sum_{j=0}^{p} c_{j} \Delta u_{r t-j}+f_{t}+\left(v_{i}+e_{i r t}\right)
$$

(4) $j_{i r t}=k j_{i r t-l}+\sum_{j=0}^{q} l_{j} \Delta u_{r t-j}+g_{t}+\left(w_{i}+u_{i r t}\right)$

where $j$ is the logarithm of the number of journeymen and where $b, c$ (over $p$ parameters), $k, l$ (over $q$ parameters) are parameters to be estimated, $f$ and $g$ are unrestricted time intercepts, $v$ and $w$ are job match effects and e and $\mathrm{u}$ are random errors. Note that, if $b=k$ in (3) and (4), we can also estimate an equivalent equation in ratio form, $r$, with $r_{i r t}=a_{i r t}-j_{i r t}$

Time series of changes in the rate of unemployment (un-logged) are shown for three EEF districts in Figure 4 and these are typical of the general picture. The change in unemployment increases steeply up to 1932 before decreasing rapidly in the next two years from which point it increases gradually. The overall shape of these graphs is not dissimilar from several of the ratio graphs in Figure 3. The equation specifications allow for lags in the reaction of the dependent variables to these cyclical movements. In the event, current and one-period lagged $\Delta u_{t}$ were sufficient to capture the complete reac tion times (i.e. $p=q=1$ in the above equations). 


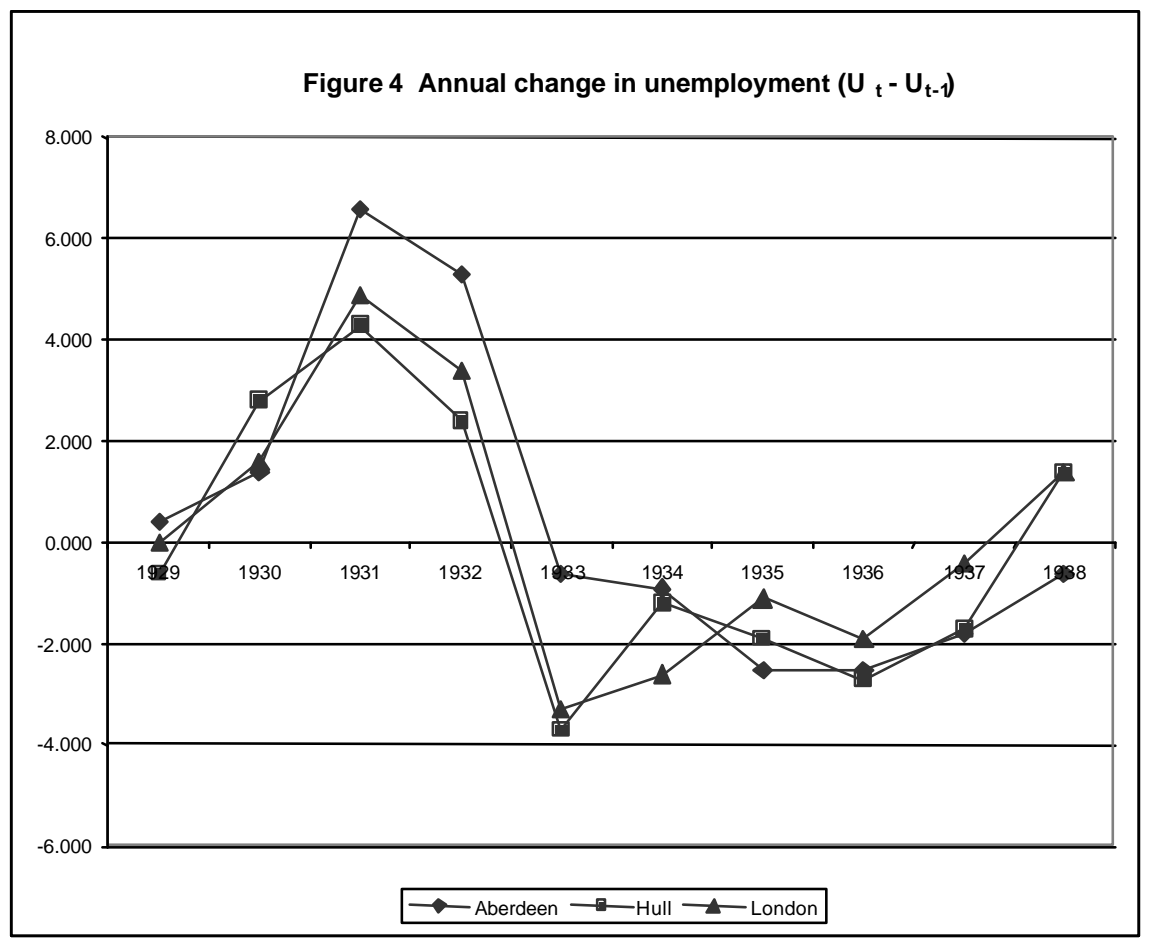

The Ordinary Least Squares estimator of equations (3) and (4) is inconsistent since the lagged dependent variables $j_{i t-l}$ and $a_{i t-l}$ are positively correlated with their respective error terms. Such bias will lead to underestimates of the speeds of adjustment of apprentices and journeymen. Provided the disturbances are serially uncorrelated, differencing the data to eliminate fixed effects and then applying instrumental variables forms the basis of a consistent estimator. Testing for second-order autocorrelation in the differenced residuals checks for a lack of serial correlation in the disturbances. To these ends, estimation is carried out using the Arellano and Bond (1991) generalised method of moments (GMM) estimator. ${ }^{27}$ Results are shown in Table 3. The ratio form of the equations is also included given almost identical coefficients on the lagged dependent variables in equations (3) and (4). For all specifications, the estimated results do not reject the null of no second-order

\footnotetext{
${ }^{27}$ Using STATA (2001), Version 7.
} 
autocorrelation (at the 5 percent level) in the differenced residuals, a critical test of consistent estimates in the Arellano and Bond approach to estimation.

These are four main sets of findings from the results in Table 2.

(a) Both apprentices and journeymen separately, together with their ratio, exhibit speedy adjustments to the changing economic conditions. In general, the estimated coefficients on the lagged dependent variables suggest that roughly 65 percent of desired adjustment is achieved in a given year. We can firmly reject the notion that apprentices enjoyed special employment protection. ${ }^{28}$

(b) Both apprentices and journeymen display procyclical adjustment in numbers employed. Accelerating unemployment during the initial economic downturn and decelerating unemployment as the Depression bottomed-out are negatively related to numbers employed.

(c) The timings of the responses to changes in unemployment differed between the two occupational groups. The full response of journeymen is captured by the current change in unemployment, with an insignificant lagged change. For apprentices, by contrast, the response was delayed; a one -year lagged unemployment change is the significant influence in this regression.

(d) Combining the two effects in (c), we find the ratio responds significantly positively to the current change in unemployment and significantly negatively to the lagged change. This is in line with the shape of the ratios shown in Figure 3.

\footnotetext{
28 As a yardstick, suppose the length of apprenticeship was guaranteed. Given apprenticeship duration of 5-7 years, we would then expect coefficients in excess of 0.8 on the lagged dependent variable in the apprenticeship equation. In other words, no more than $20 \%$ adjustment would have been achieved in a given year.
} 
While employment change for apprentices and journeymen taken separately was procyclical, the respective ratio of the two groups displayed countercyclical movements.

Table 2 GMM estimates of apprentices, journeymen and ratio employment equations, 1928-1938

\begin{tabular}{|c|c|c|c|}
\hline Dependent Variable: & $a$ & $j$ & $r$ \\
\hline$\overline{a(-1)}$ & $\begin{array}{c}0.357 \\
{[0.000]}\end{array}$ & - & - \\
\hline$j(-1)$ & - & $\begin{array}{c}0.323 \\
{[0.000]}\end{array}$ & - \\
\hline$r(-1)$ & - & - & $\begin{array}{c}0.368 \\
{[0.000]}\end{array}$ \\
\hline$\Delta u$ & $\begin{array}{c}-0.037 \\
{[0.531]}\end{array}$ & $\begin{array}{c}-0.154 \\
{[0.002]}\end{array}$ & $\begin{array}{c}0.124 \\
{[0.048]}\end{array}$ \\
\hline$\Delta u(-1)$ & $\begin{array}{c}-0.138 \\
{[0.067]}\end{array}$ & $\begin{array}{c}0.024 \\
{[0.728]}\end{array}$ & $\begin{array}{c}-0.213 \\
{[0.001]}\end{array}$ \\
\hline $\mathbf{m}_{1}$ & $\begin{array}{l}-5.60 \\
{[0.00]}\end{array}$ & $\begin{array}{l}-5.46 \\
{[0.00]}\end{array}$ & $\begin{array}{c}-6.50 \\
{[0.00]}\end{array}$ \\
\hline $\mathbf{m}_{2}$ & $\begin{array}{c}1.73 \\
{[0.08]}\end{array}$ & $\begin{array}{c}-0.22 \\
{[0.82]}\end{array}$ & $\begin{array}{c}0.92 \\
{[0.36]}\end{array}$ \\
\hline
\end{tabular}

Notes: (1) Regressions based on 936 observations.

(2) All regressions include time dummies.

(4) Figures in parenthesis are p-values.

In the light of the discussion of Section 3, these results are consistent with the scenario depicted in Figure 1. Given the severity and the speed of the onset of the Depression, firms speedily laid off unprofitable journeymen. In this initial phase, experienced apprentices either re mained profitable or, at least, involved much lower per-capita losses. As the Depression lengthened and deepened, apprentices were laid off in considerably greater numbers. Note that the actual speed of adjustment was the same for both groups. The delayed response of apprentices was due to an optimal adjustment strategy adopted in the industry. 
Those firms that employed relatively large stocks of fully, or near-fully, trained apprentices at the outset of the Depression, would have exhibited higher prope nsities to lay off journeymen. To test this proposition, I divided the EEF data into northern and southern/midland districts. (This divide is on the basis of the geographical location of EEF districts - see Appendix.) As summarised in Figure 3, the former employed, on average, far higher ratios of apprentices to journeymen.

Table 3 GMM estimates of apprentices, journeymen and ratio employment equations, 1928 - 1938: northern and midlands/southern districts

\begin{tabular}{|c|c|c|c|c|}
\hline & \multicolumn{2}{|c|}{ Northern Districts } & \multicolumn{2}{|c|}{ South/Midland District } \\
\hline Dependent Variable: & $a$ & $j$ & $a$ & $j$ \\
\hline$\overline{a(-1)}$ & $\begin{array}{c}0.376 \\
{[0.000]}\end{array}$ & - & $\begin{array}{c}0.301 \\
{[0.000]}\end{array}$ & - \\
\hline$j(-1)$ & - & $\begin{array}{c}0.262 \\
{[0.006]}\end{array}$ & & $\begin{array}{c}0.176 \\
{[0.207]}\end{array}$ \\
\hline$\Delta \boldsymbol{u}$ & $\begin{array}{r}-0.049 \\
{[0.480]}\end{array}$ & $\begin{array}{c}-0.271 \\
{[0.000]}\end{array}$ & $\begin{array}{c}-0.055 \\
{[0.685]}\end{array}$ & $\begin{array}{c}-0.114 \\
{[0.066]}\end{array}$ \\
\hline$\Delta u(-1)$ & $\begin{array}{r}-0.080 \\
{[0.402]}\end{array}$ & $\begin{array}{c}0.020 \\
{[0.851]}\end{array}$ & $\begin{array}{r}-0.210 \\
{[0.083]}\end{array}$ & $\begin{array}{c}-0.027 \\
{[0.651]}\end{array}$ \\
\hline $\mathbf{m}_{1}$ & $\begin{array}{l}-4.51 \\
{[0.00]}\end{array}$ & $\begin{array}{l}-4.65 \\
{[0.00]}\end{array}$ & $\begin{array}{l}-3.50 \\
{[0.00]}\end{array}$ & $\begin{array}{c}-2.02 \\
{[0.04]}\end{array}$ \\
\hline $\begin{array}{l}\mathbf{m}_{2} \\
\text { No. of observations }\end{array}$ & $\begin{array}{c}2.01 \\
{[0.04]} \\
600 \\
\end{array}$ & $\begin{array}{c}0.11 \\
{[0.91]} \\
600 \\
\end{array}$ & $\begin{array}{c}0.32 \\
{[0.75]} \\
336 \\
\end{array}$ & $\begin{array}{c}-1.38 \\
{[0.17]} \\
336 \\
\end{array}$ \\
\hline
\end{tabular}

Notes: See Table 2.

As shown in Table 3, repeating the employment regressions using the north-south divide produces two additional findings. First, the journeyman response to a change in unemployment in northern districts is more than double that in midlands/southern districts. Second, there is a far more significant (one-year lagged) apprentice response 
in the midlands/south compared to the north. ${ }^{29}$ These findings lend support to the notion that northern engineering firms substituted relatively cheap apprentices for journeymen as a buffer against the severe economic downturn.

\section{Conclusions}

During the trauma of the Great Depression, labour market adjustments within manufacturing industry were expressed through changes in the quantities rather than the prices of labour inputs. In both the UK and the USA, real and nominal wages were either acyclical or counter-cyclical (e.g. Bernanke and Powell, 1986; Hart, 2001). However, employment reactions were by no means limited to across-the-board cuts in the employment stock. Falls in average weekly hours were as quantitatively important as workforce reductions. Working time changes offered two advantages. They provided a rapid response mechanism to the economic downturn (Bernanke, 1986) and simultaneously helped to reduce labour costs due to the elimination of overtime premium payments (Hart, 2001).

Reductions in average hours of work in British engineering helped firms achieve an immediate employment response coupled with a reduction in per unit labour cost due to less overtime working. In parallel, moving to a higher proportion of apprentices to total workers also provided cost and adjustment advantages. On the cost side, relatively experienced apprentices may have continued to be profitable - or, at least, represented far less significant losses - in the face of severe demand reductions. As for adjustment, while there were no impediments to the lay-off of apprentices in times

${ }^{29}$ Although caution should be exercised here, since we cannot reject second-order serial correlation at the 5 per cent level in the apprentices' equation for northern districts. 
of economic necessity, their provision of relatively cheap substitute labour afforded firms time to gauge the probable length and depth of the Depression before undertaking their full employment responses. 


\section{(1) References}

Arellano, M and S. Bond. 1991. Some tests of specification for panel data: Monte Carlo evidence and an application to employment equations. Review of Economic Studies 58, 277-297.

Bean, C.R. 1990. Endogenous growth and the procyclical behaviour of productivity. European Economic Review 34, 355-363.

Bernanke, B.S. 1986. Employment, hours, and earnings in the Depression: an analysis of eight manufacturing industries, American Ec onomic Review 76, 82- 109.

Bernanke, B.S. and J. Powell. 1986. The cyclical behavior of industrial labor markets: a comparison of pre-war and post-war eras, in R. J. Gordon, ed., The American business cycle: continuity and change, Chicago, University of Chicago Press.

Hart, R.A. 2001. Hours and wages in the Depression: British engineering, 1926-1938. Explorations in Economic History 38, 478-502.

Hart, R.A. and D.I. MacKay. 1975. Engineering earnings in Britain, 1914-68. Journal of the Royal Statistical Society (Series A) 138, 32-50.

Hill, T.P., and Knowles, K.G.J.C. 1956. The variability of engineering earnings. Bulletin of the Oxford University Institute of Statistics 18, 97-139.

Marsh, A. 1965. Industrial relations in engineering. London: Pergamon.

Ministry of Labour. 1928a. Report of an enquiry into apprenticeship and training, 1925-1926. VI- Engineering, shipbuilding and ship-repairing and other metal industries, London, HMSO.

Ministry of Labour 1928b. Report of an enquiry into apprenticeship and training, 1925-1926. VII- General report, London, HMSO.

McKinlay, A. 1986. From industrial serf to wage-labourer: the 1937 apprentice revolt in Britain. International Review of Social History 31, 1-18.

Moulton, B R. 1990. An illustration of the pitfall in estimating the effects of aggregate variables on micro units. Review of Economics and Statistics 72, 33438.

Ryan, P. 1999. The embedding of apprenticeship in industrial relations: British engineering, 1925-65. In P. Ainley and H. Rainbird (eds.) Apprenticeship, London, Kogan Page.

Saint-Paul, G. 1993. Productivity growth and the structure of the business cycle. European Economic Review 37, 861-890. 
Tawney, R.H. 1909. The economics of boy labour. Economic Journal 19, 517-537

Thorley, W.G.F. 1975. A breath of steam. (Volume 1), London: Ian Allan Ltd. 


\section{Appendix: Background EEF information}

The geographical location within the UK of the EEF areas is shown in Figure A1.

The district associations within each area are listed in Table A1. This table also

indicates the districts included in the analysis of this paper. Matched unemployment

rates for 25 of the 27 districts included in the regressions were obtained from Hart and MacKay (1975). Unemployment rates for the remaining 2 districts - Northern Ireland and the West of England - were obtained from British Labour Statistics, Historical Abstract 1868 - 1968 (HMSO, 1971).

\section{Figure A1: EEF Areas}

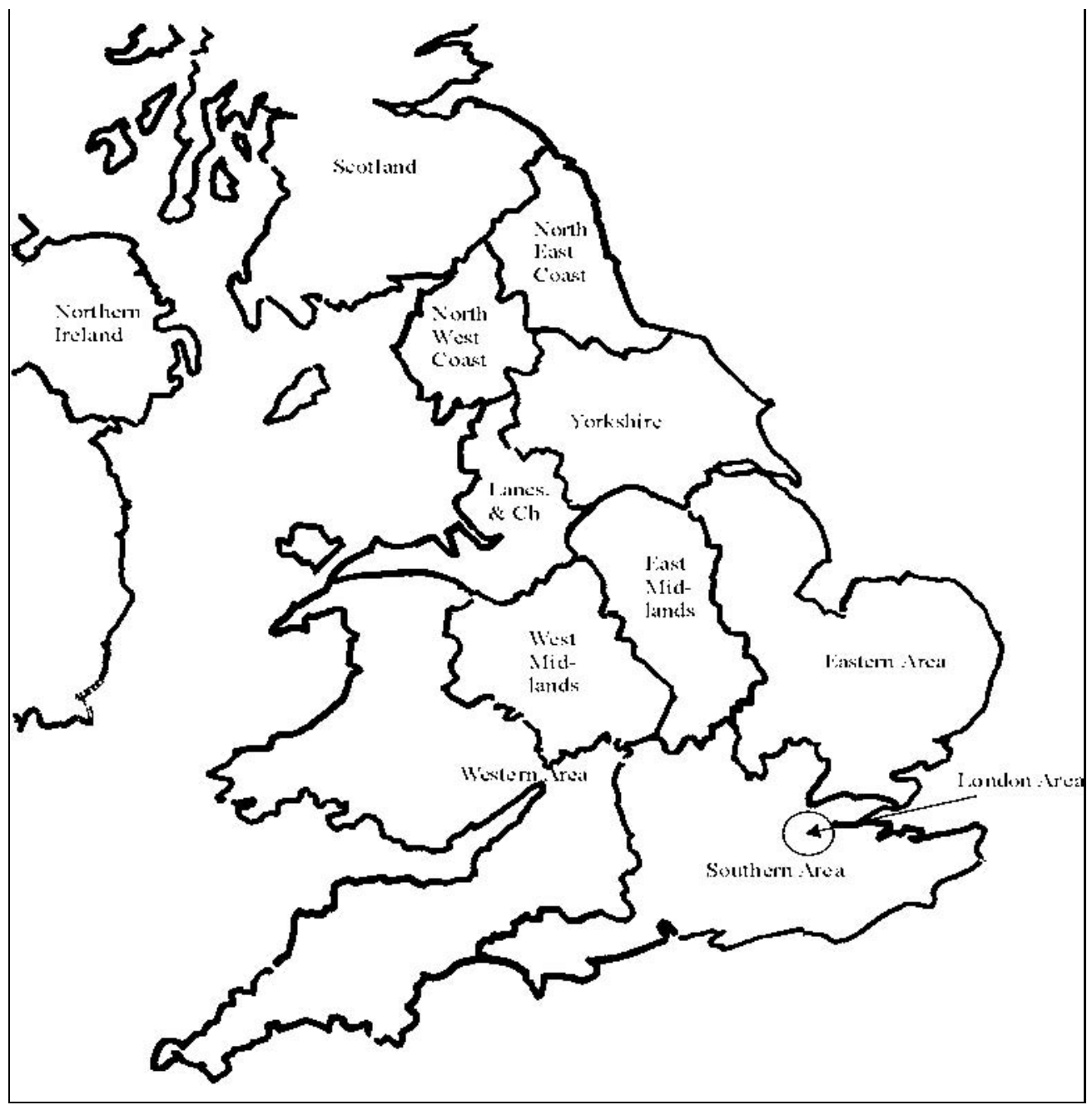


Table A1: Areas and District Associations within the EEF

\begin{tabular}{|c|c|c|c|c|c|}
\hline Area & \multicolumn{5}{|c|}{ District Associations } \\
\hline Western & West of England* & South Wales & & & \\
\hline Southern & London (outside)* & & & & \\
\hline London & London & & & & \\
\hline West Midlands & $\begin{array}{l}\text { Birmingham* } \\
\text { Shropshire }\end{array}$ & Burton & Coventry* & North Staffs & \\
\hline East Midlands & Derby ${ }^{\star}$ & Leicester* & Nottingham* & Sheffield* & \\
\hline Eastern & Bedfordshire* & Cambridge & East Anglia & Lincoln* & Peterborough \\
\hline $\begin{array}{l}\text { Lancashire \& } \\
\text { Cheshire }\end{array}$ & $\begin{array}{l}\text { Birkenhead } \\
\text { Liverpool* }^{*} \\
\text { St. Helens }\end{array}$ & $\begin{array}{l}\text { Blackburn* } \\
\text { Manchester* } \\
\text { Wigan* }\end{array}$ & $\begin{array}{l}\text { Bolton* } \\
\text { Oldham* }\end{array}$ & $\begin{array}{l}\text { Burnley* } \\
\text { Preston* }\end{array}$ & $\begin{array}{l}\text { Chester } \\
\text { Rochdale* }\end{array}$ \\
\hline Yorkshire & $\begin{array}{l}\text { Bradford } \\
\text { Keighley }\end{array}$ & $\begin{array}{l}\text { Halifa } x^{*} \\
\text { Leeds }\end{array}$ & $\begin{array}{l}\text { Heavy Woollen } \\
\text { Wakefied }\end{array}$ & Huddersfield* & Hull* \\
\hline North-West Coast & Barrow* $^{*}$ & $\begin{array}{l}\text { Border } \\
\text { Counties }\end{array}$ & & & \\
\hline North-East Coast & North-East Coast* & & & & \\
\hline Scotland & Aberdeen* & Dundee* & Kilmarnock & $\begin{array}{l}\text { Scottish } \\
\text { (North West)* }^{*}\end{array}$ & $\begin{array}{l}\text { Scottish } \\
\text { (East Coast) }\end{array}$ \\
\hline Northern Ireland & Belfast Marine & $\begin{array}{l}\text { Northern } \\
\text { Ireland* }\end{array}$ & & & \\
\hline
\end{tabular}

Note: * Associations included in regression analyses.

In Figure 3 and Table 3, the distinction is made between northern districts and midland/southern districts. The latter consist of 'Western' through to 'Eastern' in Table A1 while the former comprise the remaining districts in the table.

The EEF data on numbers of apprentices and journeymen relate to the eight occupations shown in Table A2. They were obtained from the EEF Archive (MSS.237.13/3/57-61). Only districts with an unbroken series of apprentices and journeymen for all 11 years of the analysis were included in the regressions in Tables 
2 and 3, together with the added requirement that there were no less than 10 workers in either group in each and every year. As revealed in Table A2, the most detailed information related to fitters (no excluded districts), turners (one excluded), patternmakers (eight excluded) and moulders (six excluded). Information on the remaining 4 occupations is much more sparse, mainly reflecting their relative importance within the industry. Note that 'number of observations' in Table A2 refers to numbers of districts included multiplied by 11 years.

Table A2: EEF district/occupation combinations in regressions

\begin{tabular}{|c|c|c|c|c|c|c|c|c|c|}
\hline & Fitters & Turners & $\begin{array}{l}\text { Pattern- } \\
\text { Makers }\end{array}$ & Smiths & $\begin{array}{c}\text { Boiler } \\
\text { Makers }\end{array}$ & Moulders & $\begin{array}{c}\text { Brass } \\
\text { moulders }\end{array}$ & $\begin{array}{c}\text { Brass } \\
\text { Finishers }\end{array}$ & $\begin{array}{l}\text { No. } \\
\text { obs. }\end{array}$ \\
\hline Aberdeen & $\sqrt{ }$ & $\sqrt{ }$ & $\sqrt{ }$ & - & - & $\sqrt{ }$ & - & - & 44 \\
\hline Barrow & $\sqrt{ }$ & $\sqrt{ }$ & $\sqrt{ }$ & - & $\sqrt{ }$ & $\sqrt{ }$ & $\sqrt{ }$ & $\sqrt{ }$ & 77 \\
\hline Bedfordshire & $\sqrt{ }$ & $\sqrt{ }$ & $\sqrt{ }$ & - & - & - & - & - & 33 \\
\hline Blackburn & $\sqrt{ }$ & $\sqrt{ }$ & $\sqrt{ }$ & - & - & $\sqrt{ }$ & - & - & 44 \\
\hline Bolton & $\sqrt{ }$ & $\sqrt{ }$ & $\sqrt{ }$ & - & $\sqrt{ }$ & $\sqrt{ }$ & - & - & 55 \\
\hline Burnley & $\sqrt{ }$ & $\sqrt{ }$ & - & - & - & - & - & - & 22 \\
\hline Coventry & $\sqrt{ }$ & - & $\sqrt{ }$ & - & - & - & - & - & 22 \\
\hline Derby & $\sqrt{ }$ & $\sqrt{ }$ & $\sqrt{ }$ & - & - & $\sqrt{ }$ & - & - & 44 \\
\hline Dundee & $\sqrt{ }$ & $\sqrt{ }$ & $\sqrt{ }$ & - & - & $\sqrt{ }$ & - & - & 44 \\
\hline Halifax & $\sqrt{ }$ & $\sqrt{ }$ & $\sqrt{ }$ & - & $\sqrt{ }$ & $\sqrt{ }$ & - & - & 55 \\
\hline Hull & $\sqrt{ }$ & $\sqrt{ }$ & - & - & - & $\sqrt{ }$ & - & $\sqrt{ }$ & 44 \\
\hline Leicester & $\sqrt{ }$ & $\sqrt{ }$ & $\sqrt{ }$ & - & - & $\sqrt{ }$ & - & - & 44 \\
\hline Lincoln & $\sqrt{ }$ & $\sqrt{ }$ & $\sqrt{ }$ & - & $\sqrt{ }$ & $\sqrt{ }$ & - & - & 55 \\
\hline Liverpool & $\sqrt{ }$ & $\sqrt{ }$ & - & - & - & - & - & - & 22 \\
\hline London & $\sqrt{ }$ & $\sqrt{ }$ & $\sqrt{ }$ & - & $\sqrt{ }$ & $\sqrt{ }$ & - & $\sqrt{ }$ & 66 \\
\hline Manchester & $\sqrt{ }$ & $\sqrt{ }$ & $\sqrt{ }$ & $\sqrt{ }$ & $\sqrt{ }$ & $\sqrt{ }$ & $\sqrt{ }$ & $\sqrt{ }$ & 88 \\
\hline N.E Coast & $\sqrt{ }$ & $\sqrt{ }$ & $\sqrt{ }$ & $\sqrt{ }$ & $\sqrt{ }$ & $\sqrt{ }$ & $\sqrt{ }$ & $\sqrt{ }$ & 88 \\
\hline Nottingham & $\sqrt{ }$ & $\sqrt{ }$ & - & - & - & $\sqrt{ }$ & - & - & 33 \\
\hline Oldham & $\sqrt{ }$ & $\sqrt{ }$ & - & - & - & $\sqrt{ }$ & - & - & 33 \\
\hline Preston & $\sqrt{ }$ & $\sqrt{ }$ & $\sqrt{ }$ & - & - & $\sqrt{ }$ & - & - & 44 \\
\hline Rochdale & $\sqrt{ }$ & $\sqrt{ }$ & - & - & - & - & - & - & 22 \\
\hline Scottish & $\sqrt{ }$ & $\sqrt{ }$ & $\sqrt{ }$ & $\sqrt{ }$ & $\sqrt{ }$ & $\sqrt{ }$ & $\sqrt{ }$ & $\sqrt{ }$ & 88 \\
\hline Sheffield & $\sqrt{ }$ & $\sqrt{ }$ & $\sqrt{ }$ & $\sqrt{ }$ & $\sqrt{ }$ & $\sqrt{ }$ & - & - & 66 \\
\hline Birmingham & $\sqrt{ }$ & $\sqrt{ }$ & $\sqrt{ }$ & - & - & $\sqrt{ }$ & - & - & 44 \\
\hline Wigan & $\sqrt{ }$ & $\sqrt{ }$ & - & - & - & - & - & - & 22 \\
\hline West of England & $\sqrt{ }$ & $\sqrt{ }$ & $\sqrt{ }$ & - & $\sqrt{ }$ & $\sqrt{ }$ & - & - & 55 \\
\hline Northern Ireland & $\sqrt{ }$ & $\sqrt{ }$ & - & - & - & $\sqrt{ }$ & - & - & 33 \\
\hline No. observations & 297 & 286 & 209 & 44 & 110 & 231 & 44 & 66 & 1287 \\
\hline
\end{tabular}




\section{IZA Discussion Papers}

\begin{tabular}{|c|c|c|c|c|}
\hline No. & Author(s) & Title & Area & Date \\
\hline 785 & R. Almeida & $\begin{array}{l}\text { The Effects of Foreign Owned Firms on the } \\
\text { Labor Market }\end{array}$ & 2 & $05 / 03$ \\
\hline 786 & $\begin{array}{l}\text { P. Mueser } \\
\text { K. R. Troske } \\
\text { A. Gorislavsky }\end{array}$ & $\begin{array}{l}\text { Using State Administrative Data to Measure } \\
\text { Program Performance }\end{array}$ & 6 & $05 / 03$ \\
\hline 787 & $\begin{array}{l}\text { P. Garibaldi } \\
\text { L. Pacelli } \\
\text { A. Borgarello }\end{array}$ & $\begin{array}{l}\text { Employment Protection Legislation and the Size } \\
\text { of Firms }\end{array}$ & 3 & $05 / 03$ \\
\hline 788 & $\begin{array}{l}\text { F. Büchel } \\
\text { J. R. Frick }\end{array}$ & $\begin{array}{l}\text { Immigrants in the UK and in West Germany - } \\
\text { Relative Income Position, Income Portfolio, and } \\
\text { Redistribution Effects }\end{array}$ & 1 & $06 / 03$ \\
\hline 789 & $\begin{array}{l}\text { J. A. Cabral Vieira } \\
\text { A. R. Cardoso } \\
\text { M. Portela }\end{array}$ & $\begin{array}{l}\text { Recruitment and Pay at the Establishment } \\
\text { Level: Gender Segregation and the Wage Gap } \\
\text { in Portugal }\end{array}$ & 5 & 06/03 \\
\hline 790 & $\begin{array}{l}\text { A. Cigno } \\
\text { A. Luporini } \\
\text { A. Pettini }\end{array}$ & $\begin{array}{l}\text { Hidden Information Problems in the Design of } \\
\text { Family Allowances }\end{array}$ & 3 & $06 / 03$ \\
\hline 791 & M. Güell & $\begin{array}{l}\text { Fixed-Term Contracts and the Duration } \\
\text { Distribution of Unemployment }\end{array}$ & 1 & $06 / 03$ \\
\hline 792 & $\begin{array}{l}\text { L. Borghans } \\
\text { B. ter Weel }\end{array}$ & $\begin{array}{l}\text { What Happens When Agent T Gets a } \\
\text { Computer? The Labor Market Impact of Cost } \\
\text { Efficient Computer Adoption }\end{array}$ & 5 & $06 / 03$ \\
\hline 793 & T. Palokangas & $\begin{array}{l}\text { Foreign Direct Investment, Labour Market } \\
\text { Regulation and Self-Interested Governments }\end{array}$ & 3 & 06/03 \\
\hline 794 & $\begin{array}{l}\text { P. Frijters } \\
\text { M. A. Shields } \\
\text { S. Wheatley Price }\end{array}$ & $\begin{array}{l}\text { Investigating the Quitting Decision of Nurses: } \\
\text { Panel Data Evidence from the British National } \\
\text { Health Service }\end{array}$ & 1 & 06/03 \\
\hline 795 & B. T. Hirsch & $\begin{array}{l}\text { Reconsidering Union Wage Effects: Surveying } \\
\text { New Evidence on an Old Topic }\end{array}$ & 3 & $06 / 03$ \\
\hline 796 & P. Apps & Gender, Time Use and Models of the Household & 5 & 06/03 \\
\hline 797 & $\begin{array}{l}\text { E. Bratberg } \\
\varnothing . \text { A. Nilsen } \\
\text { K. Vaage }\end{array}$ & $\begin{array}{l}\text { Assessing Changes in Intergenerational } \\
\text { Earnings Mobility }\end{array}$ & 2 & 06/03 \\
\hline 798 & $\begin{array}{l}\text { J. J. Heckman } \\
\text { J. A. Smith }\end{array}$ & $\begin{array}{l}\text { The Determinants of Participation in a Social } \\
\text { Program: Evidence from a Prototypical Job } \\
\text { Training Program }\end{array}$ & 6 & $06 / 03$ \\
\hline 799 & R. A. Hart & $\begin{array}{l}\text { General Human Capital and Employment } \\
\text { Adjustment in the Great Depression: } \\
\text { Apprentices and Journeymen in UK Engineering }\end{array}$ & 2 & $06 / 03$ \\
\hline
\end{tabular}

An updated list of IZA Discussion Papers is available on the center's homepage www.iza.org. 